\title{
Apical extrusion of debris after hand, engine-driven reciprocating and continuous preparation
}

\author{
Extrusão apical de "debris" após o preparo manual e \\ mecanizado oscilatório e contínuo
}

\begin{abstract}
Purpose: This in vitro study assessed the amount of debris extruded apically after preparation with different techniques.

Methods: Sixty healthy, extracted, human mandibular incisors were randomly divided into 3 groups: Group A - hand crown-down technique; Group B - crown-down technique with enginedriven rotary reciprocating instruments; Group C - Protaper: engine-driven continuous rotary instrumentation. The roots were immersed in $2.3 \mathrm{~mL}$ of distilled water. After preparation, the water in each tube was filtered to collect solid material extruded, and the filters were weighed using a precision scale. Data were analyzed by Kolmogorov-Smirnov and Kruskal-Wallis tests at the 0.05 level of significance.

Results: The statistical analysis showed that group $\mathrm{C}$ had significantly higher values of debris than groups $A$ and $B$.

Conclusion: The instrumentation using a continuous rotary technique, Protaper, produced greater apical extrusion than the hand and engine-driven crown-down techniques. The direction of instrumentation, whether cervical-apical or apical-cervical, seems to be a more important factor influencing apical extrusion than whether the instrumentation was performed by hand or was engine-driven.
\end{abstract}

Key words: Root canal preparation; crown-down technique; periapical tissue; Protaper

\section{Resumo}

Objetivo: Este estudo, in vitro, avaliou a quantidade de extrusão apical de "debris", após o preparo químico-mecânico do canal radicular, utilizando diferentes técnicas.

Metodologia: Sessenta incisivos inferiores humanos hígidos foram aleatoriamente divididos em três grupos: Grupo A: técnica coroa-ápice manual; Grupo B: técnica coroa-ápice mecanizada com sistema de rotação oscilatória; Grupo C: Protaper, técnica mecanizada com sistema de rotação contínua. As raízes foram imersas em 2,3 mL de água destilada. Após os preparos, a água destilada de cada amostra foi filtrada, e o filtro de papel, contendo o material sólido extruído, foi pesado em uma balança analítica de precisão. Os dados foram analisados estatisticamente pelos testes Kolmogorov-Smirnov e Kruskal-Wallis ao nível de significância de 0,05 .

Resultados: A análise estatística demonstrou que o grupo $C$ apresentou valores superiores de "debris" do que os grupos A e B.

Conclusão: A técnica rotatória contínua com Pro-taper produziu maior quantidade de extrusão apical do que as técnicas coroa-ápice manual e mecanizada com sistema de rołação oscilatória. A direção da instrumentação, se cérvico-apical ou ápico-cervical, parece ser o fator mais determinante na extrusão de "debris" independente desta ser realizada manual ou mecanizada.

Palavras-chave: Preparo do canal radicular; técnica coroa-ápice; tecido periapical; Protaper

\author{
Simone Bonato Luisi a \\ Alice Cunegatti Zottis a \\ Caroline Scheeren Piffer a \\ Andrea Cabral de Mello Vanzin a \\ Rosane Angélica Ligabue a
}

a Pontifical Catholic University of Rio Grande do Sul, Porto Alegre, RS, Brazil

\author{
Correspondence: \\ Simone Bonato Luisi \\ Faculdade de Odontologia da PUC-RS \\ Avenida Ipiranga, 6681 - Prédio 6 \\ Porto Alegre, RS - Brazil \\ 90619900 \\ E-mail:simoneluisi@terra.com.br
}

Received: April 12, 2009

Accepted: July 17, 2010

Conflict of Interest Statement: The authors state that there are no financial and personal conflicts of interest that could have inappropriately influenced their work.

Copyright: (C) 2010 Luisi et al.; licensee EDIPUCRS. This is an Open Access article distributed under the terms of the Creative Commons AttributionNoncommercial-No Derivative Works 3.0 Unported License. 


\section{Introduction}

Apical extrusion of debris during chemical and mechanical preparation of root canals is one of the most common problems found by endodontists (1). Biologically, all irritating agents must be removed from the root canal by chemical and mechanical preparation so that cleaning and debridement are adequate but periapical tissues are not damaged (2). However, the removal of necrotic pulp tissues and irrigation may cause extrusion of irritants to periapical tissues regardless of the instrumentation technique used. This extrusion may cause pain, discomfort and persistent inflammation (3-5). As all instrumentation techniques produce some amount of apical extrusion $(4,6-8)$, the choice of a technique should also take into consideration how well the apical extrusion of debris can be controlled.

Sonic, ultrasonic and cervical enlargement techniques produce less apical extrusion of debris than hand instrumentation (9). Apical extrusion of debris tends to be greater with hand instrumentation than with techniques that use rotary forces $(2,5,8,10)$ because the files may act as pistons that push irrigating solutions and debris towards the apex (11). Conversely, rotary instrumentation may move debris along the files, which may result in debris being expelled cervically (12).

The performance of a balanced force technique is similar to that of engine-driven techniques, but the former extrudes less irrigating solution than the Profile .04 system (5). According to Ferraz et al. (5), there is no significant difference in the volume of irrigating solution or amount of debris extruded apically among engine-driven techniques that use Profile .04, Quantec 2000 and Pow-R instruments. The hand balancedforce technique promotes significantly less extrusion of irrigating solution and debris than the hybrid hand instrumentation. The latter, in turn, results in significantly greater extrusion of irrigating solution and debris than engine-driven techniques. Apical extrusion may be greater when hybrid techniques are used because of the type of file movements used in instrumentation of the apical third. The ProTaper and System GT systems do not differ significantly in the amount of apical extrusion of bacteria (13), but the Protaper instrumentation system extrudes significantly more debris than the Profile system (12).

The purpose of this in vitro study was to assess the amount of apical extrusion of debris after chemical and mechanical preparation of root canals using a hand crown-down technique, an M-4 reciprocating system and the Protaper continuous rotary system (Dentsply-Maillefer ${ }^{\mathrm{TM}}$ ).

\section{Methodology}

Sixty healthy, extracted human mandibular incisors with completely formed apices and straight canals were used. These teeth, measuring $18-20 \mathrm{~mm}$ and extracted due to clinical indications, were selected from the collection of the Endodontic Laboratory Course of the School of Dentistry, Pontifícia Universidade do Rio Grande do Sul (PUCRS),
Porto Alegre, Brazil. Teeth were excluded if they had more than one canal, internal calcifications or resorptions confirmed on periapical radiographs.

Teeth were stored in saline solution until the periodontal ligament was scaled with periodontal curettes (Neumar 13-14, São Paulo, Brazil). They were then rinsed in tap water for 1 minute and dried at room temperature. Specimens were packed and autoclaved (M9 UltraClave, Dabi Atlante, São Paulo, Brazil) for 40 minutes at $126^{\circ} \mathrm{C}$ and 20 psi pressure. Selected teeth were randomly numbered from 1 to 60 with a black pencil on the buccal surface. Before the beginning of the experimental procedures, all specimens were kept in saline solution for 48 hours for hydration.

All procedures were performed by 2 operators trained for the use of the systems. Tooth roots were covered with wet gauze and were vertically held between the jaws of a vice (40 $\mathrm{mm}$ Baby Vice); the pulp chamber was opened with an air-turbine handpiece and a \#1012 round diamond bur (KG Sorensen, São Paulo, Brazil). A \#10 file was introduced in the canal until its tip reached the apex, and the working length was established at $1 \mathrm{~mm}$ from the apex. All teeth were then placed in sterilized tubes with $2.3 \mathrm{~mL}$ of distilled water; the tooth crown was fixed to the tube top and the root was submersed in the liquid.

The teeth were randomly divided into 3 groups (A, B and C). The root canals were irrigated with $2 \mathrm{~mL}$ of $1 \%$ sodium hypochlorite, (Virex 2\%; Johnsons \& Johnsons, Saõ Paulo, Brazil; diluted in distilled water) after the use of each instrument. The irrigating solution was kept in a $10-\mathrm{ml}$ disposable syringe with a $25 \mathrm{X} 4$ needle (B-D) calibrated with a silicone stop at $3 \mathrm{~mm}$ from the working length. A\#10 suction cannula (B-D) was used for aspiration.

In groups A and B, Flexofile (Dentsply-Maillefer, Ballaigues, Switzerland) instruments were used 4 times. In group C, NiTi Protaper (Dentsply-Maillefer) instruments were used. These instruments have a triangular and convex transverse section, which reduces the contact area between instrument and dentin and increases their cutting action. In addition, they have a variable helicoidal angle, which increases their cutting action and the amount of debris extruded out of the root canal. They also have variable tapering and inactive tips. The instruments were disposed of after being used in four root canals.

The first instruments in the root canal, in all groups, were \#10 and \#15 files used with hand balanced-force movements to the working length. These files were called initial instruments and were used to make the root canal accessible to the subsequent instruments.

\section{Group A: hand crown-down technique}

Files were used with balanced-force movements: a quarter of turn to the right, half turn to the left and withdrawal of the instrument until it was loose in the canal. The \#45, \#40, $\# 35$, \#30, \#25, \#20 files were used in this sequence until the working length was reached. The apex was prepared at the working length with a file of smaller caliber than the one that reached it. After that, three other files of successively 
greater taper were used. Before each instrument change, the initial instrument was used again to remove obstructions or elbows that might have formed.

\section{Group B: crown-down technique with engine-driven reciprocating rotary system}

The M-4 system performs reciprocating movements to the right and left at a 30-degree amplitude and at a 10:1 gear reduction. Sequential \#45, \#40,\#35,\#30, \#25 and \#20 files connected to the reciprocating system (M-4) were used until the working length was reached. The files were introduced gently into the root canal until resistance was met. The operator introduced and pulled out the files moving them against the root canal walls. The apical preparation was performed as in group A. Before each instrument change, the initial instrument, connected to the reciprocating system, was used again to remove obstructions and elbows that might have formed.

\section{Group C: mechanical technique with continuous rotary system}

An electric motor (EndoPlus, Driller) with speed and torque control was used at $250 \mathrm{rpm}$ and 2 N.cm. Gentle pushpull motions (tapping motion) that applied pressure in the cervical-apical direction were repeated five times for each instrument. The following sequence was used:

- The first rotary instrument (SX; 2-19\% taper) was used to prepare the cervical and middle thirds of the root canal and prevent any obstructions to the access to the apical third.

- After that, the S1 instrument (2\%-11\% taper) was used to shape the cervical and middle thirds.

- The S2 instrument (4\%-11.5\% taper) was used to prepare the middle and apical regions of the root canal. The SX, $\mathrm{S} 1$ and $\mathrm{S} 2$ instruments were used until initial resistance was met, when the operator did not push the instrument any further.

- An F1 instrument (7\%-5.5\% taper) was used at the working length.

After preparation was completed, $2 \mathrm{~mL}$ of $1 \%$ sodium hypochlorite was used for irrigation along with aspiration and irrigation of $17 \%$ trisodium EDTA (Iodontec). The solution was stirred with the initial file and was left in the root for 3 minutes. After that, $2 \mathrm{~mL}$ of $1 \%$ sodium hypochlorite was used for the final irrigation, and the root canal was suctioned.

\section{Method of weighing debris}

To obtain measurements, $80-\mathrm{g} / \mathrm{m}^{2}$ paper filters $12,5 \mathrm{~cm}$ in diameter were used; they were weighed in a precision scale (AG 200, Gehaka) before and after filtering the solution in the tubes. The tubes were opened after the end of the procedures, and the paper filters were used to filter it. The debris was separated from the distilled water solution. The residual material in the tube and in the tooth roots was rinsed with a small amount of distilled water. The filters were dried in a stove (Soc. Fabbe Ltda) at $100^{\circ} \mathrm{C}$ for 12 hours.
The extrusion weight was calculated and statistically analyzed using the non-parametric Kolmogorov-Smirnov test for each group. The Kruskal-Wallis non-parametric test was used for comparisons among the three groups. The level of significance was set at $5 \%$.

\section{Results}

The results of the Kruskal-Wallis test revealed a significant difference between the three groups Table 1. Group C (continuous rotary instrumentation - Protaper) had significantly greater amounts of debris than the other groups. The amounts for Groups A (hand instrumentation - crown-down) and $B$ (reciprocating engine-driven instrumentation - M-4) were not significantly different.

Table 1. Comparison of the quantity of debris among the experimental groups.

\begin{tabular}{cccccc}
\hline Group & N & Average $^{*}$ & SD & $\begin{array}{c}\text { Average } \\
\text { Rank }\end{array}$ & $P$ \\
\hline Group A & 19 & 0.0038 A & 0.0027 & 21.24 & $\leq .01$ \\
Group B & 18 & $0.0033^{\text {A }}$ & 0.0034 & 17.08 & \\
Group C & 20 & $0.0179^{\text {B }}$ & 0.0045 & 47.10 & \\
\hline
\end{tabular}

*Means followed by the same letter are not statistically different.

\section{Discussion}

The extrusion of debris to the periapical region may cause inflammation and flare-ups after endodontic treatment. This extrusion may also cause serious systemic diseases, such as endocarditis, brain abscesses and sepsis, especially in medically-compromised patients $(14,15)$.

Although this study did not evaluate the difference in apical extrusion between vital and necrotized teeth, this discussion is relevant. Vital teeth have a pulp stump that may serve as a barrier to the extrusion of debris, but such resistance is not found in necrotized teeth. However, possible overinstrumentation in cases of pulpectomy, in which some extrusion may occur, may lead to more serious symptoms postoperatively than in cases of pulp necrosis. In an in vivo study, Salzgeber and Brilliant (16) showed that vital pulp tissues help to control lateral and apical penetration of the irrigating solution. In cases of necrosis, the solution disperses when it reaches the apical lesion. Moreover, there is a difference in the amount of in vivo and in vitro extrusion because of the presence of periapical tissues that prevent excessive extrusion of debris (17).

Curvature and presence of more than one canal are factors that may affect the final amount of apical extrusion (12). Therefore, only single-rooted teeth with straight canals were used in this study to eliminate variables that might interfere with results.

The diameter of the apical foramen is greater in young patients than in older people. Therefore, young teeth may have a greater probability of flare-ups due to greater apical extrusion. However, Al-Omari and Dummer (18), 
Mc Kendry (19), and Fairbourn et al. (9) found no significant correlation between apical diameter and amount of extruded debris. As dentin mineralization is less intense in young teeth, these teeth would also be expected to be more liable to wear, causing greater extrusion (12). As it is not possible to control this factor in teeth, Ruiz-Hubard et al. (2) used acrylic models to simulate root canals; however, simulated canals are limited study models that do not reproduce dentin characteristics. Therefore, in this study, as well as in the ones conducted by Tanalp et al. (12) and Sümer and Akpinar (13), extracted human teeth were used.

Various factors, such as instrumentation technique, instrument size, apical stop and type of irrigating solution, affect the amount of apical extrusion $(6,16)$. Rotary instrumentation techniques (Protaper and HERO Shaper) reduce the number of instruments used for root canal preparation, which may be seen as an advantage at first. However, Tanalp et al. (12) compared Protaper systems with other continuous rotary techniques and found significantly greater amounts of extruded debris when using the Protaper technique. In our study, this technique had significantly better apical extrusion results than those found for a hand technique and a reciprocating rotary technique. Although the Protaper System uses fewer instruments, it promotes greater dentin wear in a shorter time because of its greater cutting capacity and taper. The other techniques in this study (hand and alternating rotary technique) required the use of more files with only one, lower taper $(0.2 \mathrm{~mm})$. Their cutting capacity was, therefore, lower, and the root canal was prepared slowly and gradually until the working length was reached. The tapering of the Protaper files favors the preparation of the apical third as soon as instrumentation begins. Thus, wear occurs early throughout the whole canal because the instruments reach the working length in the beginning of the preparation, which causes greater apical extrusion.

Reciprocation engine-driven techniques reduce work time, which is an advantage for both the operator and the patient. This technique uses conventional files and does not produce significantly greater apical extrusion than the hand technique. Nevertheless, attention should be paid when using reciprocating engine-driven instrumentation in teeth with curved canals because it may create elbows and root canal deviations.

\section{Conclusions}

The results of this in vitro study showed that the endodontic instrumentation using a continuous rotary technique (Protaper) produced greater apical extrusion than hand and engine-driven crown-down techniques. The direction of instrumentation, whether cervical-apical or apical-cervical, seems to be a more determinant factor of apical extrusion than whether instrumentation was performed by hand or was engine-driven.

\section{References}

1. Mangalam S, Rao CV, Lakshminarayanan L. Evaluation of apically extruded debris and irrigant using three instrumentation techniques. Endodontology 2002; 14:19-23.

2. Ruiz-Hubard EE, Gutmann JL, Wagner MJ. A quantitative assessment of canal debris forced periapically during root canal instrumentation using two different techniques. J Endod 1987;13:554-8.

3. Lee SJ, Lee CS, Strittmatter EJ. An in vitro comparison of root canal content extrusion using ultrasonic and hand instrumentation. Endod Dent Traumatol 1991:7:65-8.

4. Lambrianidis T, Tosounidou E, Tzoanopoulou M. The effect of maintaining apical patency on periapical extrusion. J Endod 2001;27: 696-8.

5. Ferraz CC, Gomes NV, Gomes BP, Zaia AA, Teixeira FB, SouzaFilho FJ. Apical extrusion of debris and irrigants using two hand and three engine-driven instrumentation techniques. Int Endod J $2001 ; 34: 354-8$

6. Vande Visse JE, Brilliant JD. Effect of irrigation on the production of extruded material at the root apex during instrumentation. J Endod 1975; 1:243-6.

7. Beeson TJ, Hartwell GR, Thornton JD, Gunsolley JC. Comparison of debris extruded apically in straight canals: conventional filings versus profile .04 Taper series 29. J Endod 1998;24:18-22.

8. Reddy SA, Hicks ML. Apical extrusion of debris using two hand and two rotatory instrumentation techniques. J Endod 1998;24: 180-3.

9. Fairbourn DR, McWalter GM, Montgomery S. The effect of four preparation techniques on the amount of apically extruded debris. J Endod 1987; 13:102-8.
10. Bidar M, Rastegar AF, Ghaziani P, Namazikhah MS. Evaluation of apically extruded debris in conventional and rotary instrumentation techniques. J Calif Dent Assoc 2004;32:665-71.

11. Brown DC, Moore BK, Brown CE Jr, Newton CW. An in vitro study of apical extrusion of sodium hypochlorite during endodontic canal preparation. J Endod 1995;12:587-91.

12. Tanalp J, Kaptan F, Sert S, Kayahan B, Bayirl G. Quantitative evaluation of the amount of apically extruded debris using 3 different rotary instrumentation systems. Oral Surg Oral Med Oral Pathol Oral Radiol Endod 2006;101:250-7.

13. Er K, Sümer Z, Akpinar E. Apical extrusion of intracanal bacteria following use of two engine-driven instrumentation techniques. Int Endod J 2005;38:871-6.

14. Debelian GJ, Olsen I, Tronstad L. Bacteremia in conjunction with endodontic therapy. Endod Dent Traumatol 1995;1 1:142-9.

15. Savarrio L, Mackenzie D, Riggio M, Saunders WP, Bagg J. Detection of bacteraemias during nonsurgical root canal treatment. J Dent 2005;33:293-303.

16. Salzgeber RM, Brilliant JD. An in vivo evaluation of the penetration of an irrigating solution in root canals. J Endod 1977;3:394-8.

17. Seltzer S, Soltanoff W, Sinai I, Goldenberg A, Bender IB. Biologic aspects of endodontics. 3. Periapical tissue reactions to root canal instrumentation. Oral Surg Oral Med Oral Pathol 1968;26:534-46.

18. al-Omari MA, Dummer PM. Canal blockage and debris extrusion with eight preparation techniques. J Endod 1995;21:154-8.

19. McKendry DJ. Comparison of balanced forces, endosonic and stepback filing instrumentation: quantification of extruded apical debris. J Endod 1990;16:24-7. 